Dossiê - Para além do “ativismo judicial” e da “Judicialização da política” DOI: $10.5433 / 2176-6665.2016 \mathrm{v} 21 \mathrm{~N} 1 \mathrm{P} 44$

\title{
UM CANIBAL NO BANCO DOS RÉUS? ENTRE O CANIBALISMO E O VILIPÊNDIO A CADÁVER EM UM CASO JURÍDICO
}

\author{
Clark Mangabeira $^{1}$
}

\begin{abstract}
Resumo
Em 2007, uma pequena cidade do Centro-Oeste brasileiro apareceu no panorama da imprensa nacional devido ao caso de um homicídio que envolveu atos de canibalismo. O objetivo deste trabalho é articular as narrativas jurídicas da acusação e da defesa, constantes nos autos do processo, no tocante às categorias canibalismo e vilipêndio a cadáver. Trata-se, em sentido amplo, de um estudo de caso sobre canibalismo em contexto urbano e suas representações jurídico-discursivas, articuladas a partir da interpretação de eixos como violência, nojo, simpatia e silêncios, destacados dos textos e documentos processuais. Longe de procurar motivos, por fim, interessa a construção jurídica do caso concreto e seus desdobramentos semânticos.
\end{abstract}

Palavras-chave: Canibalismo. Vilipêndio a cadáver. Direito. Ciências sociais.

\section{A Cannibal in the dock? Between Canibalism AND CORPSE VIOLATION IN A LEGAL CASE}

\begin{abstract}
In 2007, a Brazilian Midwest's small town appeared in the panorama of the national press due to a murderer case that involved acts of cannibalism. The objective of this work is to articulate the legal narratives of the prosecution and the defense, contained in the court documents, in relation to the categories of cannibalism and corpse violation. It is, in a broad sense, a case study of cannibalism in urban context and its legal discursive representations, compound from the interpretation of axes
\end{abstract}

1 Professor-adjunto do Departamento de Antropologia da Universidade Federal do Mato Grosso (UFMT), Brasil. mangabeira.clark@gmail.com 
such as violence, disgust, sympathy and silence, categories derived from the texts and legal documents. Far from looking for reasons, finally, what matters is the legal construction of the case and its semantic developments.

Key words: Canibalism. Corpse violation. Law. Social sciences.

violência, se e quando pensada apenas como um conceito, possui
uma infinidade de nuances que tornam essa categorização um exercício quase estéril em alguns contextos. Na realidade específica das práticas jurídicas, organizadas em lógicas e estéticas próprias, tal conceitualização parece tornar-se inócua frente à necessidade de descrição dos casos, de trazer a realidade passada do crime para mais perto dos discursos variados que sobrepõem-se nas idas e vindas dos processos penais, marcados pelas várias vozes que compõem a acusação e a defesa. Naquele plano jurídico, o processo penal apresenta, ainda, diversos momentos, cada qual com uma coloração específica que confere novas vertentes de argumentação aos polos do caso, fazendo a adequação - em tese - do fato jurídico ao fato criminoso.

$\mathrm{O}$ caso aqui analisado versa sobre um triângulo amoroso que culminou na morte de um dos envolvidos, seguida de atos de canibalismo. Apesar de divulgados na mídia, optou-se pela não revelação dos nomes das personagens a fim de não adentrar desnecessariamente na seara da identificação pessoal: é o caso e sua articulação textual que interessam em primeiro plano, não a curiosidade pela personificação dos criminosos.

Paralelamente, enquanto um conjunto de discursos congelados em uma parte específica do processo - os documentos escritos apresentados entre o oferecimento da ação penal e a sentença de pronúncia, somados aos documentos referentes à condenação pelo Tribunal do Júri reduzida a termo nos autos do processo -, o caso possui uma dinâmica textual que é o eixo central da análise. 
Esta debruça-se sobre os textos marcados no papel, sobre as falas registradas que constroem cenas e contextos do crime a partir da perspectiva do discurso chapado, em especial os depoimentos em sede policial e os interrogatórios dos envolvidos no crime. A perspectiva oral, das falas e argumentações do Tribunal do Júri em si, bem como as nuances performáticas de todas as audiências, embora fundamentais para a formação da imagem jurídica do caso, não foram possíveis de serem acessadas. Assim, os limites deste trabalho são as capas que enquadram o processo registrado por escrito.

O ponto de partida é o desfecho condenatório transformado em peça escrita. A condenação, embora ápice do processo penal como um todo, está baseada no lastro textual anterior. Partindo da condenação pelo júri, voltaremos ao registro da noite do crime e ao desenvolvimento jurídico do caso.

\section{II}

O Tribunal do Júri foi marcado para o final de Julho de 2009 e terminou no mesmo dia. Após os debates, o Conselho de Sentença se reuniu para que cada jurado sigilosamente votasse e decidisse o futuro de G., marceneiro, homem simples e conhecido pelos arredores da cidade.

De acordo com o Termo de Julgamento, na página 358 do processo, os jurados tiveram que votar (sim ou não) a respeito de dois blocos de perguntas. O primeiro versou sobre o crime de homicídio doloso (artigo 121 do Código Penal). Perguntava-se se na madrugada do dia 23 de Novembro de 2007, A. sofreu os ferimentos a golpes de faca, causa de sua morte, descritos no laudo constante nas folhas 41 e 42 do mesmo processo; se G. desferiu os golpes contra A.; se os jurados absolveriam o réu; se G. cometera o crime por motivo fútil ciúme em relação a A. -; se G. agiu mediante recurso que dificultou 
ou impossibilitou a defesa de A., qual seja, o fato deste estar caído e seriamente ferido; e se existiriam atenuantes a favor do réu.

$\mathrm{O}$ segundo bloco incidiu sobe o crime de vilipêndio ao cadáver (artigo 212 do Código Penal), sobre o qual os jurados foram inqueridos a respeito de decidirem se, na madrugada do mesmo dia 23 de Novembro de 2007, o cadáver de A. "sofreu vilipêndio, desprezo, consistente em ser aberto na altura do tórax, com extração de coração, fígado e testículos, bem como no fato de (G.) passar o pênis nas nádegas do cadáver"; se G. foi o autor; se os jurados absolvem o réu; e se haveria atenuantes a seu favor.

G. foi condenado. A sentença condenatória transitou em julgado no começo de Agosto de 2009. Vencido em todos os quesitos contra ele, houve, contudo, a incidência de duas atenuantes de confissão, uma para cada crime. Para o homicídio, prevaleceu a tese das duas qualificadoras (motivo fútil e impossibilidade ou dificuldade de defesa da vítima), sendo fixada a pena em 15 anos de reclusão. No caso do crime de vilipêndio, G. foi condenado a 1 ano e 3 meses de detenção, mais o pagamento de 15 dias multa (1/30 do salário mínimo por dia multa). Segundo o cálculo da pena, nas folhas 413 e 414 do processo, já tendo sido cumuladas as penas de ambos os crimes e, sobre essa soma, incidindo os cálculos que regem a progressão do regime e a data final da condenação, a previsão para a liberdade é fevereiro de 2024.

No dia seguinte ao julgamento pelo Tribunal do Júri, o site do Ministério Público da cidade em questão publicou uma nota intitulada "Caso de canibalismo é julgado", indicando sumariamente os dados da condenação. Afirmando que o réu ficou conhecido nacionalmente por atos de canibalismo, há um evidente distanciamento entre a consolidação narrativa que foi proposta aos jurados e a manchete veiculada: na primeira, o crime de vilipêndio ao cadáver narra os cortes e a retirada dos órgãos, sem citar qualquer ingestão de 
carne humana, ao passo que a nota foca na ideia de canibalismo, prática de fato registrada nos autos, mas cuja configuração temática transmutou-se para se tornar vilipêndio. Do canibalismo ao vilipêndio, intraprocessualmente, houve um distanciamento narrativo, enquanto, extraprocessualmente, mereceu atenção o primeiro: sobrepujandose ao homicídio, foi o ato canibal que varreu as manchetes regionais sobre o caso, dentre as quais a veiculada por um jornal eletrônico em novembro de 2007, intitulada "Homem confessa ato de canibalismo". Entre ser canibal e ser homicida, assassino, foi a primeira "identidade" que chocou os ânimos midiáticos.

Deixando de lado os inúmeros discursos sobre o caso, foca-se nos provenientes dos autos do processo. Desde a prisão em flagrante de G., que fora ajudado por um adolescente, à época dos fatos com 15 anos, aqui chamado de X., o ponto inicial deste texto é o oferecimento da denúncia pelo Ministério Público até a sentença condenatória exposta acima. Não houve presença no julgamento pelo júri, de modo que as qualificações orais realizadas naquele não serão reproduzidas. Contudo, qualquer processo de competência daquele tribunal (crimes dolosos contra a vida) assenta-se sobre uma plêiade de documentos que o antecedem e que o delineiam. O júri é a instância final, de efetiva condenação ou absolvição, mas que se projeta para trás, sobre o lastro processual e discursivo; sobre as idas e vindas entre defesa, acusação e juiz; sobre as provas colhidas e consumadas em 447 páginas que dão embasamento e suporte às horas que defesa e acusação tem para resumi-las para os jurados. Por mais instigante, interessante e até empolgante que um júri possa ser, entre o ato e a sentença, houve quase dois anos de diálogos na esfera jurídica, restando, para além das falas e dinâmicas orais importantes daquela instituição, um conjunto probatório, acusatório e defensório escrito que norteia as fabulações orais. 
Longe de explorar qualquer veracidade dos fatos, "o que realmente aconteceu", a possibilidade de significar algo é a possibilidade de trafegar por um conjunto de significantes e formas de narrar. O que se acessa é uma fabulação que se precipita entre o dizível e o indizível, cujo próprio ato de narrar domestica-a semanticamente, estabilizando um amplo conjunto de variáveis que se estabeleceram desde o ato em si, inacessível para nós: os porquês, as possibilidades, as dinâmicas, as validades, os infortúnios, enfim, a dinâmica de um assassinato, no mínimo brutal, é aprisionada pelo narrado, gerida entre as possibilidades do que pode ou não ser falado e escrito na esfera jurídica. Nos autos do processo, há uma poética, uma estética e uma retórica próprias que definem G., X. e A. em um contexto situacional específico de violência. Acessa-se, através dos autos, não a visão dos personagens, nem suas falas como se diretamente coletadas e conscientemente vinculadas à "verdade", mas sua domesticação e seu uso por esferas de poder que se definem triplamente entre acusação, defesa e julgamento. Cumpre ainda ressaltar que o foco é a ação penal movida contra G., visto que X., por ser menor à época do fato, respondeu por ato infracional e, embora suas falas e depoimentos estejam registrados no processo, não é sua "condenação" que está em análise diretamente. Assim, é sobre esses usos, sobre as construções semânticas discursivas do que aconteceu na madrugada do dia 23 de novembro de 2007, que os autos e eu nos debruçamos, resultando em uma nova metainterpretação do acontecido a partir dos documentos processuais: este texto.

\section{III}

Antes de interpretar o que foi registrado no processo, cabe frisar que dentre as 447 páginas de documentos, nem todas expressam algum conteúdo importante de definição dos réus, da vítima e da 
visão do julgador. Há inúmeras páginas que atendem unicamente às necessidades burocráticas, informando idas e vindas dos autos, solicitações e respostas quanto à locomoção dos presos, despachos de mero expediente realizados pelo juiz, decisões interinas quanto às possibilidades de documentações serem apresentadas ou não, observações quanto a localização de uma testemunha, desistências de jurados, dentre outras folhas de papel que "andam" com o processo. Embora esses documentos não especifiquem as personagens ou o caso em si - sendo, assim, deixados fora do escopo deste trabalho -, jurídica e burocraticamente são indispensáveis para a qualificação do caso, circunstanciando possibilidades recursais, prazos e diversas outras características do sistema de justiça.

Paralelamente, há, delimitadas pela letra da lei, determinadas peças processuais que, de fato, tematizam sobre o caso em si. Se estamos no universo do Direito, convém prestar atenção às regras que embasaram o presente processo no tocante àquelas ordenação e burocracia necessárias, determinando estas peças processuais que importam realmente para o julgamento do caso.

O Tribunal do Júri tem como competência julgar os crimes dolosos contra a vida. Trata-se de um processo bifásico, no qual a primeira fase incide sobre o juízo de admissibilidade da ação penal e a segunda, sobre o juízo de mérito, ou seja, o júri enfim (Conselho de Sentença) decidindo se o réu é culpado ou inocente. De acordo com a legislação que regia o caso à época do julgamento, na primeira fase, é um juiz singular que reconhece ou não, na sentença de pronúncia, a admissibilidade da acusação, determinando, se for o caso, o julgamento do réu pelo Tribunal do Júri. Sua competência é reconhecer a materialidade do fato e a existência de indícios suficientes de autoria ou participação, sendo-lhe permitido, contudo, inocentar o réu caso julgue provada a inexistência do fato, se o acusado não for autor ou partícipe, se o fato não constituir infração penal, ou se demonstrada 
causa de isenção de pena ou de exclusão do crime-como, por exemplo, a legítima defesa -, tudo nos termos dos artigos 413 e 415 do Código de Processo Penal.

Decorre, portanto, que, do oferecimento da denúncia - e consequente instauração da ação penal - até a sentença de pronúncia, as provas acerca do fato e da autoria já são demonstradas no processo diante do juiz singular, sendo possível, inclusive, inocentar o réu. $\mathrm{O}$ percurso até o júri - segunda fase -, caso a sentença de pronúncia o indique, já é travado pelo diálogo entre defesa e acusação, com a construção das versões que cabem a ambos. Adicionalmente, antes do oferecimento da denúncia, vale lembrar que o inquérito policial é o "conjunto de atos praticados pela função executiva do Estado com o escopo de apurar a autoria e materialidade [...] de uma infração penal, dando ao Ministério Público elementos necessários que viabilizem o exercício da ação penal" (RANGEL, 2010, p. 74), de maneira que a atividade policial dá base à denúncia, estando, pois, os depoimentos e demais provas colhidas em sede policial servindo tanto à decisão do Ministério Público de acusar o investigado, quanto como conjunto probatório do processo.

Trata-se de três momentos distintos, mas interligados, cujo ápice - o júri - baseia-se no lastro dado pelo inquérito e pelas provas colhidas ao longo do processo. As narrativas que, desde a sede policial, perpassam a acusação e a defesa, e constroem os personagens, apresentam-se ordenadas como peças centrais, quais sejam, os depoimentos em sede policial, a denúncia, a resposta prévia à acusação, as provas de acusação e defesa, os esclarecimentos dos peritos, as alegações finais da defesa e da acusação, a decisão de pronúncia e a sentença condenatória, peças processuais nas quais há a caracterização da cena para o trâmite semântico do processo.

Como há uma necessária continuidade semântica entre as peças - temas e versões desenvolvidos, repetidos e ampliados a cada 
passo processual -, interessa a delimitação dos significados que se atribui à violência documento após documento. Seguindo Veena Das (2008), se a violência é algo sempre volátil, as formas através das quais tal narrativa é construída ancoram a definição da situação violenta em termos de gramáticas, estéticas, poéticas e retóricas que delimitam e impulsionam os seus efeitos. A violência acaba sendo tecida nessas formas, pelas formas e não sob elas, de modo que o que se fala e o que não se fala sobre G., A. e X. informam e formam suas trajetórias no contexto criminal localizado temporalmente: as gramáticas e os discursos agem no/pelo tempo, para frente e parta trás, evidenciando e traduzindo o contexto situacional da violência realizada.

Ainda na esteira de Das $(2007,2008)$, as narrativas congeladas do poder público usam palavras escritas que se precipitam sobre um processo material e temporal cujo mote é a busca pelo contexto, materialidade e autoria da violência. Trazer a cena ocorrida para as páginas de um processo que tenta realizar uma resolução para o caso é uma tentativa de reconstruir e domesticar discursivamente fatos extraordinários, cujas estórias estão temporalmente em construção nos termos de um nível ordinário, aqui, jurídico. Igualmente, a linguagem e as narrativas do processo são uma ação de recriação da violência para criação de significados passíveis de serem entendidos e, na lei, julgados. Há, portanto, em 447 páginas, uma construção que versa sobre a regulação das incertezas e dos fatos imorais realizados, culminando em uma gestão de formas de caracterização que incidem sobre os atores envolvidos no homicídio de A. Assim, focando essas narrativas congeladas, resvala pelas bordas da poética processual um homicídio e um ato de canibalismo que se transformou em vilipêndio ao cadáver. 


\section{IV}

A denúncia foi oferecida em dezembro de 2007.

Sobre os delitos, às nove horas de 23 de novembro de 2007, o adolescente $X$. compareceu à delegacia de polícia para contar o que ocorrera na madrugada anterior. Segundo seu depoimento em sede policial, X. se encontrou às vinte e três horas do dia 22 com G. em um bar, afirmando que com ele mantinha um relacionamento amoroso há quatro dias, bem como outro com A., há mais tempo. X. conta que pediu a uma senhora chamada M. para lhe emprestar sua casa, para onde ele e G., bêbados, foram manter relações sexuais, sendo surpreendidos por A., que teria gritado "[...] você está transando com outro homem, você não falou que iria transar apenas comigo?". Ato contínuo, A. pegou uma faca de cozinha e partiu para cima de G., que, por sua vez, pegou uma faca que trazia consigo e desferiu um golpe no tórax de A.. Machucado e caído, G. e X. desferiram diversos golpes contra A., matando-o. Em seguida, segundo X., G. passou o pênis nas nádegas do cadáver e, utilizando-se da sua faca, fez um corte profundo na perna da vítima e tentou degolá-lo. Posteriormente, teria G. afirmado que iria retirar o coração e o fígado de A. para fritar e comer com farinha. Sem fritura ou farinha, contudo, G. assim o fez: abriu o tórax do cadáver para retirar seu fígado e coração, comeu um pedaço do primeiro e deu outro para o adolescente que também o provou, embora o tenha descrito como amargo. Ele não ingeriu tudo. G., entretanto, ainda pegou um copo de cozinha, encheu-o de sangue dentro do tórax do morto e o bebeu, afirmando estar gostoso. X. não quis o sangue. Com medo de ser morto, o adolescente foi à delegacia.

Nas palavras congeladas do Termo de Declaração em Auto de Prisão em Flagrante Delito e Apreensão de menor Infrator, tem-se o inteiro teor do documento:

Às 09h00min, do dia 23 de novembro de 2007, na Delegacia 
de Polícia Civil de onde presente encontrava-se o

Dr. Delegado de Polícia Civil, comigo, Escrivão de seu cargo, ao final assinado, aí compareceu $\mathbf{X}$., filho de e natural de nascido aos $\mathrm{xx} / \mathrm{xx} / \mathrm{xxxx}$,

brasileiro, solteiro, residente na Av. Sabendo ler e escrever. Sobre os fatos, respondeu: QUE, o declarante se encontra assistido pelos conselheiros e representantes do Conselho Tutelar de Q Q $\overline{\mathrm{UE}, \mathrm{a}}$ respeito dos fatos afirma o declarante que em data de ontem (22.11.2007), por volta das $23 \mathrm{~h} 00 \mathrm{~min}$, encontrou no bar do W., localizado na Av. neste município de a pessoa de G., o qual conhece há aproximadamente trinta dias; QUE, esclarece o declarante que é homossexual e há quatro dias estava mantendo um relacionamento com $\mathrm{G}$. e A.; QUE, na ocasião em que encontrou G. combinaram em manter relação sexual na casa da M., localizada na Av. neste município; QUE, pediram para $\mathrm{M}$. emprestar a casa para o declarante e G., manter relação sexual; QUE, por volta das $00 \mathrm{~h} 30 \mathrm{~min}$, chegou ao local A., e aproveitando que a porta estava apenas encostada adentrou, e surpreendeu o declarante e G., mantendo relação sexual; QUE, neste momento A. ficou irritado e disse para o declarante: "...você está transando com outro homem, você não falou que iria transar apenas comigo...", e ato contínuo pegou uma faca que estava sobre a pia da cozinha e tentou esfaquear o declarante e G.; QUE, afirma o declarante que nesta oportunidade, G. pegou a faca que trazia consigo e estava próxima a cama, e iniciaram uma luta corporal com A., ocasião em que G. desferiu um golpe contra A., vindo a atingi-lo na região do tórax; QUE, aproveitando que A. estava caído, o declarante tomou a faca de A. e junto com G. desferiram diversos golpes contra A., causando-lhe a morte momento em que G. passou o pênis na bunda de A. e disse: "...ai que cuzinho gostoso..."; QUE, ato contínuo o declarante utilizando a faca, fez um corte profundo na perna de A., QUE, afirma o declarante que G., utilizando a faca tentou degolar A. e após fez um corte non tórax de A., abrindo-o momento em que G. disse o seguinte “... eu vou retirar o coração e o fígado para fritar e comer com farinha..."; QUE, afirma o declarante que G. retirou o fígado e o coração de A., comeu uma parte e deu um pedaço do fígado de A. para o declarante comer; QUE, esclarece que ao receber o pedaço do fígado de A., comeu um pedaço, mas não gostou e 
jogou o restante; QUE, afirma o declarante que G. pegou um copo que estava sobre a mesa da cozinha e passou no tórax de A. que estava aberto, e retirou um pouco de sangue e após beber disse: "...ai que sangue gostos" e ofereceu ao declarante, mas o declarante não aceitou; QUE, afirma o declarante que $\mathrm{G}$. também cortou os testículos de A.; QUE, posteriormente G. disse para o declarante comparecer nesta Unidade Policial e assumir a autoria do crime, pois o declarante é menor de idade; QUE, afirma o declarante que após o crime o declarante ficou com medo de ser morto por G., e compareceu nesta Delegacia de Polícia durante a madrugada e relatou os fatos; QUE, os policiais dirigiram-se até a residência de G. e conduziram ele até esta Delegacia de Polícia. Nada mais. Seguem as assinaturas. (Destaques em negrito originais do processo. Optou-se pela omissão dos elementos identificatórios dos envolvidos. Processo, 2007, pp. 15 e 16).

Após o conhecimento dos fatos, policiais dirigiram-se ao local do então suposto crime. De acordo com um deles,

[...] a Guarnição deslocou-se ao palco do crime onde a vítima, em óbito, encontrava-se deitado sobre um colchão, totalmente nu e com várias perfurações provadas por arma branca a altura do peito, sinais de haver sido degolado, castrado e vísceras espalhadas pelo interior do imóvel que anteriormente era um bar e atualmente residência; QUE, também havia partes de órgãos, aparentemente coração e fígado espalhados pelo chão; QUE o menor declarou que juntamente com o autuado comeram partes dos órgãos da vítima e inclusive haviam tomado seu sangue. QUE, a Guarnição deslocou-se até a residência do autuado G. [...] o qual estava deitado em sua cama, nu, sujo de sangue e com dois cortes na altura do braço esquerdo e da perna esquerda [...]. (Processo, 2007, p. 8).

G., já na delegacia, foi informado sobre seus direitos e garantias individuais. Sobre o caso, afirmou que, na madrugada do dia 23 de novembro de 2007 estava fazendo sexo com o adolescente citado quando foi surpreendido por A. que, enciumado, já que também tinha um relacionamento com $X$., pegou uma faca e atingiu $G$. na perna. $O$ 
interrogando revidou e passou a golpear seu atacante com a faca que trazia consigo. Após a morte de A., G. confessou que, junto com X., passou a cortar a vítima, permanecendo aproximadamente uma hora tirando suas vísceras, fígado e coração, e comendo-os em parte, além de tomarem seu sangue. Depois, G. afirma ter passado o seu pênis nas nádegas de A., que se encontrava morto e nu. Por volta das três horas da madrugada, o interrogando disse que foi para casa. Segue seu interrogatório completo, tal qual o Termo de Interrogatório em Auto de Prisão em Flagrante Delito e de Apreensão de Menor Infrator:

Às 10:00 horas do dia vinte e três do mês de novembro do ano de dois mil e sete, nesta cidade de , na sede da Delegacia de Polícia, comigo Escrivão de Polícia, na sequência do auto de prisão em flagrante delito em que é conduzido G., passou-se ao interrogatório do preso de nome G., RG no e CPF brasileira, natural da cidade de de nacionalidade xx/xxxx, filho de $\mathrm{e}$ nascido aos $\mathrm{xx} /$ residente na Rua e com endereço de trabalho:

Sabendo ler e escrever. Preliminarmente foi o interrogado cientificado pela Autoridade Policial quanto aos seus direitos individuais constitucionalmente previstos, em especial os de receber assistência de familiares ou de informações que reputar úteis à sua autodefesa; o direito de conhecer a identidade do autor de sua prisão e, se admitida, prestar fiança e livrar-se solto. Cientificado da imputação que lhe é feita nesses autos e das provas contra si existentes. Perguntando sobre a sua residência, meios de vida ou profissão, oportunidades sociais, lugar onde exerce a sua atividade, respondeu: QUE, não tem condições financeiras de constituir advogado e dependerá da Defensoria Pública; QUE, reside com seus pais; QUE, é separado; QUE, não trabalha; QUE, não tem vida social; Perguntado sobre sua vida pregressa, notadamente se foi preso ou processado alguma vez e, em caso afirmativo, qual o juízo do processo, se houve suspensão condicional ou condenação, qual a pena imposta e se a cumpriu, respondeu: QUE, nunca foi preso nem processado; Perguntado sobre outros dados familiares e sociais: QUE, não tem outros dados familiares, salvo o já declarado acima; 
Ao ser interrogado pela Autoridade Policial, às perguntas respondeu: QUE, declara que por volta de 00:30 horas desta data estava no interior da residência localizada na Av. nesta cidade, fazendo sexo com o adolescente X., o qual é homossexual quando foi surpreendido pela vítima A., o qual também estava mantendo um relacionamento sexual com o adolescente e, A., enciumado ao surpreender o interrogado sobre o adolescente, apanhou uma faca de serra que estava sobre a mesa da residência e desferiu um golpe que atingiu a perna do interrogando; QUE, o interrogando portava uma faca cabo de madeira e com esta faca desferiu golpes contra a vítima; QUE, declara também que o adolescente portava uma faca com cabo de plástico na cor preta e também começou a golpear a vítima; QUE, o interrogando juntamente com o adolescente passaram a cortar a vítima, tirando coração, fígado e outras vísceras e em seguida comeram parte do coração e do fígado; QUE, permaneceram aproximadamente uma hora tirando as vísceras da vítima e comendo parte de seus órgãos; QUE, também tomaram sangue da vítima; QUE, por volta das 03:00 horas o interrogando foi para a sua casa e momentos depois policiais militares lá compareceram; QUE, quando os policias chegaram na casa do interrogando o interrogando ainda não havia tomado banho e estava todo ensanguentado; QUE, declara que estava embriagado; QUE, após ceifarem a vida da vítima, arrancarem suas vísceras e comerem parte e ainda tomaram o sangue o interrogando ainda tirou seu pênis e passou nas nádegas da vítima, após despi-lo parcialmente; QUE, foi desferido diversos golpes de faca contra a vítima, afirmando o interrogando que não sabe quantos, pois tanto o interrogando como o adolescente desfeririam golpes de faca contra a vítima, bem como ambos tiraram as vísceras da vítima e comeram, além de tomarem o sangue; Perguntando se é verdadeira a acusação que lhe é feita, respondeu: QUE, sim,; se não sendo verdadeira a acusação, se tem algum motivo particular a que atribuí-la, se conhece a pessoa ou pessoas a quem deva ser imputada a prática do crime e quais sejam, e se com elas esteve antes da prática da infração ou depois dela, respondeu: QUE, é verdadeira a imputação contra sua pessoa; Onde estava ao tempo em que foi cometida a infração e se teve notícia desta, respondeu: QUE, estava na residência, palco dos fatos, mantendo relação sexual com o adolescente X. e 
após a barbárie foi para sua casa onde policiais militares o prenderam; Perguntado sobra as provas já apuradas, respondeu: QUE, sim; Perguntado se conhece as vítimas e testemunhas já inquiridas ou por inquirir e desde quando, e se tem o que alegar contra elas respondeu: QUE, sim, conhece os policiais; Perguntado se conhece o instrumento com que foi praticada a infração, ou qualquer objeto que com esta se relacione e tenha sido apreendido, respondeu: QUE, sim, pois a faca tipo peixeira, cabo de madeira, pertence ao interrogando; Perguntado se tem algo mais a alegar em sua defesa, respondeu: QUE, não; QUE, havia um mês que estava se relacionando sexualmente com o adolescente. Nada mais disse nem lhe foi perguntado. Lido e assinado, fica este termo fazendo parte integrante do Auto de Prisão em Flagrante Delito epigrafado. (Destaques em caixa alta originais do processo. Optou-se pela omissão dos elementos identificatórios dos envolvidos. Processo, 2007, p. 17-18).

O Ministério Público ofereceu a denúncia, afirmando que "autor e adolescente, já se aproveitando do fato do ofendido estar caído, seriamente ferido e sem chances de se defender, começaram a the golpear covardemente com as facas que portavam, vindo a, com isso, eliminar sua vida" (Processo, 2007, p. 3), além de, "com o ofendido já morto, G. e o adolescente infrator começaram uma sessão de atos repulsivos e condenáveis"' (Processo, 2007, p. 3), retirando seus órgãos e comendo-os em parte.

Em dezembro de 2007, aconteceram os interrogatórios diante do magistrado com a presença do Ministério Público e da Defensoria Pública. G. afirmou que conhecia A. e que semanalmente jogavam sinuca. Nunca tivera relacionamento com ele, nem com $X$. antes do incidente. Sobre o caso, ele afirmou que A. chegou à casa e, enciumado, deu uma facada na sua perna esquerda. G. teria, então, se afastado. Pegou uma faca e "partiu para cima" de A., dando duas punhaladas no seu peito, que caiu em seguida. Após o embate, o depoente disse ter bebido um pouco mais e se dirigido para fora da casa para urinar. 
Ao retornar, viu X. furando o corpo e abrindo o tórax da vítima até a barriga, além de ter cortado o pescoço, e que aparentava estar meio "doidão", pegando os órgãos de A. e jogando-os contra o depoente. G. negou ter tomado sangue ou comido partes dos órgãos. Em detalhes, registrado nos autos, G. afirmou:

Que conhece a denúncia. Desconhece as provas produzidas. Que não tem nada a alegar contra as testemunhas arroladas na denúncia. Nunca foi preso e nem processado. Mora numa edícula no fundo da casa dos pais. É pedreiro, operador de máquina e pintor. Sua renda mensal de um salário mínimo aproximadamente. Que não é usuário de droga. Tem vício em cigarro. Não é alcóolatra, mas às vezes chega a ingerir um litro de caipira. É católico e frequenta a igreja semanalmente. Conhece a vítima há quinze anos. Que semanalmente tinha contato com A., porque jogava sinuca com o mesmo. Tinha amizade com a vítima. Que nunca brigou ou discutiu com a vítima. Que nunca teve nenhuma desavença com a vítima. Que nunca teve relacionamento sexual com A., a vítima, apenas amizade. Que conhece X., o menor, desde que este era criança. Conhece toda a família de X.. Conhece X. porque às vezes conversava com o avô deste, que inclusive tem as pernas apuntadas (sic). Que raramente tem contato com $X$.. Que antes do fato em tela, não tinha mantido relação sexual com X.. Quanto ao crime esclarece que: estava no bar do W.. No bar também estava X.. Era por volta das 20:00 horas. Que M., companheira do W., pediu para X. ajudar a fazer mudança dela para casa onde o crime ocorreu. Que M. pediu para o depoente ajudar. Que o depoente e X. fizeram a mudança, por volta das 21:00 horas terminaram a mudança. $\mathrm{M}$. levou duas garrafas de catuaba e de pinga. Que o depoente e X. passaram a beber pinga. Que M., segundo $X_{\text {., }}$ colocou um pó na bebida do depoente sem este perceber. Que X. disso (sic) isso após a prisão. Que M. saiu do local. Que em dado momento, o depoente e X. mantiveram relação sexual. Que terminaram a relação, vestiram suas vestes e, por voltas das 01:00 hora, chegou A. Esclarece que depois de 10 minutos após o ato sexual chegou A. Que A. chegou com uma faca pequena na mão. Que A. chegou com uma faca pequena na mão. Que A. falou para X. que este estava traindo sua pessoa (A.). Que 
X. disse que não tinha nada a ver. Que A. falou para o depoente o seguinte: "que isso G. pra que fazer isso". Que nesse momento A. foi em direção ao depoente e deu uma facada na perna deste (depoente). Que A. segurava a faquinha "como para dar uma punhalada", ou seja ao inverso do uso normal de uma faca. Que o depoente levou uma facada na perna e se afastou. A. ficou parado. Que o depoente pegou a faca que estava sob a mesinha, segurou-a da mesma forma que A. e partiu para cima deste dando duas facadas "punhaladas" no peito de A. Que A. caiu, não sabe se morto ou desmaiado. Que o depoente bebeu mais um copo de pinga (pouquinho) pegou um copo e foi urinar fora da casa. Quando retornou viu X. furando o corpo de A. e abrindo o tórax até a barriga. Que X. também cortou o pescoço de A.. Que X. aparentava estar meio "doidão". Que X. pegou os órgãos de A. e jogou contra o corpo do depoente. O depoente nega ter tomado sangue ou comido parte do fígado de A.. Que não é verdade que o depoente ou $X$. fritaram parte do corpo para comer. Que não viu X. comer ou beber sangue. Não sabe informar como A. ficou sabendo da relação sexual, pois quando chegou o ato já tinha acabado. Talves (sic) A. viu a relação pela fresta da parede. Que a faca utilizada pelo depoente tinha cabo de madeira e não era preta. Acha que $X$. fez uso da faca de cabo preto. Que está em cela separada dos demais presos, apenas com o preso

(Optou-se por omitir informações que identificassem os envolvidos. Processo, 2007, p. 62-63).

X. foi chamado na condição de testemunha para prestar depoimento em juízo em maio de 2008. Segundo seu novo relato, X. disse que não participou dos golpes de faca, que foi G. quem abriu e arrancou os órgãos da vítima e que iria vendê-los, que ninguém comeu nenhum pedaço dos mesmos (embora afirme que G. teria bebido o sangue), além de ter negado qualquer relacionamento amoroso. Ademais, afirmou que tinha dito o contrário em sede policial, pois seguia instruções de G., que ameaçara matá-lo caso não as cumprisse. Nos autos,

JUIZ: consta da denúncia que o senhor e o acusado G. 
teriam, ao dia 23 de novembro de 2007, assassinado A., mediante golpes de faca. É verdade isso?

DEPOENTE: Não, senhor.

JUIZ: O que aconteceu?

DEPOENTE: Eu tava... Ele que matou o rapaz.

JUIZ: Quem matou?

DEPOENTE: O J.G. O J.G. matou o rapaz.

JUIZ: Quem é J.G.?

DEPOENTE: O que tava comigo, né?

JUIZ: Que é o acusado G.?

DEPOENTE: É, o G.

JUIZ: O G.?

DEPOENTE: Sim, senhor.

JUIZ: Ele tem apelido de J.G.?

DEPOENTE: J.G..

JUIZ: E ele matou a vítima por que razão?

DEPOENTE: Ah, eu não sei.

JUIZ: O que aconteceu?

DEPOENTE: Não, assim... Estava lá em casa, né? Aí a M., que é mulher do W., largou do W.. Aí ele chegou e falou pra minha mãe assim, falou: "Ô, T., a senhora não tem pra você alugar uma casa pra mim?", ela falou: "Oh, aqui eu não posso alugar casa não, agora para você não", ele falou: "Tá bom, né?". Aí eu fui lá na casa do W., do W.: "Por que, W., que tá acontecendo aí, que você brigou com a M.?", "Não, mano". Aí já tava tomando uns gole, né? Aí eu fui na casa do seu O. Aí tinha um J.G. que tava lá no boteco do W.. Aí aluguei a casa pra ele, conversei com seu O. e aluguei a casa pra ele. Ai o A. veio e ajudou, o que morreu, ajudou a arrumar a casa, assim, arruma as 'coisa'. Aí no lugar, ele começou a tomar cachaça, aí onde os dois se desentenderam, deu a facada, né? 
JUIZ: O senhor quer dizer que eles passaram a tomar cachaça e em meio a isso, se desentenderam e ocorreram os golpes de faca?

DEPOENTE: Sim. Aí tinha. Aí a M. comprou dois litros de Pinga, né? Aí começou tomar.

JUIZ: Quantos golpes de faca foram desferidos na vítima?

DEPOENTE: Não sei. Quando não sei.

JUIZ: O senhor participou disso?

DEPOENTE: Não.

JUIZ: Depois que a vítima já estava no chão, o acusado G. continuou a esfaqueá-la?

DEPOENTE: Sim, senhor. Continuou, aí... Assim, abriu a barriga dele, aí começou a arrancar os órgãos dele.

JUIZ: Arrancou o coração, fígado, intestino, é isso?

DEPOENTE: Sim, senhor.

JUIZ: O senhor ajudou?

DEPOENTE: Aí eu fui e falei... Aí ele falou pra mim: "Agora vai lá assinar. Se não for assinar, eu mato você e mando...", como que é? "Eu mato você e mando um cara lá matar a sua mãe".

JUIZ: Quem disse isso?

DEPOENTE: O G.

JUIZ: Certo,

DEPOENTE: Aí eu fui...

JUIZ: Ele retirou os órgãos, e fez o quê?

DEPOENTE: Ia vender, né? Agora ia vender não sei pra quem.

JUIZ: Comeu?

DEPOENTE: Não. Ninguém comeu os órgãos dele. 
JUIZ: Bebeu o sangue?

DEPOENTE: Bebeu o sangue, bebeu.

JUIZ: Quem bebeu?

DEPOENTE: O G..

JUIZ: Por quê? O senhor também?

DEPOENTE: Não, senhor.

JUIZ: O senhor também não comeu parte desses órgãos?

DEPOENTE: Não, senhor.

JUIZ: O senhor tinha algum relacionamento amoroso com o acusado G.?

DEPOENTE: Não, senhor.

JUIZ: E com a vítima A.?

DEPOENTE: Também não, senhor.

JUIZ: O que consta da denúncia é isso.

DEPOENTE: Ah, o que consta é isso.

JUIZ: Consta da denúncia que o senhor teria um relacionamento amoroso, tanto com G. quanto com o A..

DEPOENTE: Mas nesse...

JUIZ: E nesse dia, o A. teria flagrado o senhor e o G. praticando sexo.

DEPOENTE: Não, senhor.

JUIZ: E com ciúmes teria partido para cima de vocês.

DEPOENTE: Isso aí não tem nada a ver não.

JUIZ: O senhor é homossexual?

DEPOENTE: Não, senhor.

JUIZ: Como surgiu essa história?

DEPOENTE: Isso ficou, que foi o delegado que tava 
falando, né? Aí que ele mandou. Que ele mandou falar assim: "Você responde o quê que o delegado falar pra você", o G. falou pra mim dentro da casinha. Aí fui respondendo.

JUIZ: O senhor já conhecia o G. fazia quanto tempo?

DEPOENTE: Uns... Um ano assim.

JUIZ: Conhecia o A. também?

DEPOENTE: Não. O que morreu não.

JUIZ: Ministério Público?

MP: Sem pergunta.

JUIZ: Defesa?

DEFESA: Sem pergunta.

(Processo, 2007, p. 28, 29, 30).

Por fim, em suas alegações finais, o Ministério Público reiterou que o adolescente e G. ceifaram a vida de A., conforme o laudo pericial. Flagrandoos durante a relação sexual, A. teria partido para cima de G. com uma faca e, durante o embate, teria caído no chão, apunhalado por G. Inconsciente, ambos golpearam à faca $\mathrm{A}$. e, em seguida, realizaram "uma sessão de atos repulsivos e condenáveis em face do respectivo cadáver, abrindo seu corpo na altura do tórax, arrancando coração, fígado e testículos. [...] e comeram parte do fígado e do coração" (Processo, 2007, p. 168). Defendendo, portanto, estar provada a qualificação de G. como autor do crime (graças à confissão tanto em sede policial, quanto durante o interrogatório) e a materialidade do fato (em razão do Laudo do Exame de Corpo e Delito - Exame Necroscópico constante nos autos às folhas 55 e 56), o promotor requereu que o réu fosse pronunciado por homicídio duplamente qualificado (motivo fútil - ciúmes - e recurso que impossibilitou ou dificultou defesa da vítima) combinado com o crime de vilipêndio a cadáver.

Encerrou, assim, a acusação. 
A defesa prévia de G. foi breve. A defensoria pública afirmou que "o acusado é inocente e não concorda com os termos da denúncia, reservando-se o direito de discutir o mérito por ocasião do oferecimento de suas alegações derradeiras" (Processo, 2007, p.89). Assim, a tese sustentada com base nos depoimentos coletados, apresentada nas alegações finais, incide primordialmente sobre a hipótese de que não existiriam testemunhas que presenciaram os fatos (todas as testemunhas arroladas pela defesa foram no sentido de versar sobre a idoneidade moral de G., ao passo que as arroladas pela acusação basicamente os policiais - definem, principalmente, o estado no qual se encontrava G. após a prisão em flagrante). Paralelamente, sustenta que todos os depoimentos e a versão única da reprodução simulada dos fatos definem que a vítima, A., estava munida de uma arma branca e que fora ela quem teria partido para cima de G., no primeiro momento, restando ao réu defender-se contra o ataque.

Para a defesa, a conduta do réu deixou de ser ilícita por que ele agira em legítima defesa, utilizando-se moderadamente dos recursos disponíveis, ou seja, da faca que carregava consigo, para evitar a agressão injusta da vítima que, enciumado, partira para atacar sua integridade física. Sobre a agravante de impossibilidade de defesa, contesta a defesa que ela não existiu, pois quem ataca deve esperar uma reação, como houve no caso. Já a agravante de motivo fútil foi repelida devido ao fato de que quem estaria enciumado seria A., ao ver o companheiro - X. - mantendo relação sexual com outro.

Sobre o crime de vilipêndio ao cadáver, para a defesa não há provas da participação do acusado, já que em juízo G. afirmou que fora X. quem abrira e retirara os órgãos da vítima. “Assim, G. não pode ser responsabilizado pelo crime de vilipêndio ao cadáver até mesmo por que contra ele só existe a versão do menor que tenta se isentar da culpa" (Processo, 2007, p. 184). 
Resta ainda que duas testemunhas de defesa notaram que o acusado teria "uma pequena falha mental, o que dificulta a conversa com o mesmo" (Processo, 2007, p. 141) e que "ele não é muito normal [...]. Que quando o requerido bebe, ele se comporta como criança" (Processo, 2007, p. 142), um incidente de sanidade mental, trazido pelas duas testemunhas, que, baseado em laudos periciais posteriores, presentes no processo, foi superado.

Por fim, pediu a defesa a absolvição sumária do réu pelo crime de homicídio, tendo em vista a existência da legítima defesa, bem como a absolvição do crime de vilipêndio a cadáver pela insuficiência de provas.

\section{VI}

A plêiade derecursos discursivos utilizadas por ambas as partes denota a tentativa de reconstrução da violência, com suas múltiplas incidências e qualificações, em um espaço e em uma temporalidade novos, chapados, o da ação penal, com vistas ao convencimento do juiz, em um primeiro momento, e dos jurados, posteriormente. Se as falas são transformadas em textos escritos, a atenção ao que importa semanticamente percorre um escrutínio que busca regular as certezas e incertezas, as falas e os silêncios do caso em pauta.

Não se pode perder de vista de que se trata de um contexto interativo triplo, acusação-defesa-magistrado/júri, no qual o órgão julgador é o foco dos convencimentos. Na pragmática do processo, de acordo com os pormenores do uso tático das paixões descrito por Bailey (1983), deve haver uma destreza na manobra das emoções pelos atores sociais, utilizadas como recursos de comoção e até racionalização, que sirva para reificar domínios semânticos defendidos pelos atores em cena. Na interação social, o jogo político entre aquilo que se quer demonstrar para os demais e aquilo que não se quer que eles saibam 
é também um exercício de poder, cujo ponto nevrálgico é a persuasão dos outros a agirem conforme uma definição predeterminada.

Se o foco está em narrativas congeladas públicas, a interação dinâmica da fala é conformada no congelamento textual, ao qual juiz, defesa e acusação se voltam de tempos em tempos, servindo o congelamento ao princípio básico, mas influente, de que nenhuma das três instâncias lembrar-se-á de tudo que foi dito pormenorizadamente dias, quiçá meses ou anos depois. A questão, contudo, é que todas as emoções, detalhes e minúcias da interação que ocorreu nos encontros entre defesa, acusação e juiz, devem, ao menos, ser trazidas minimamente para dentro do processo. Algo deve garantir, gramaticalmente, a efervescência oral interativa que ocorreu na coleta dos depoimentos, de maneira a lembrar os envolvidos das emoções acionadas nos contextos específicos em função da necessidade de convencimento do juiz e dos jurados.

Nesse sentido, a produção dos pontos principais das teses de defesa e acusação, com base nos depoimentos colhidos em sede policial e em juízo, reflete a sistemática de domesticação que opera na rede de significados trocados entre os dois polos durante a qualificação do acusado G.. Focando, para além do homicídio, no fato de que tanto a defesa quanto a acusação deram atenção especial ao crime de vilipêndio a cadáver com cadeias lexicais muito diferentes, operouse lógicas léxico-discursivas no congelamento dos depoimentos orais que divergem entre si. Embora não se tenha falado diretamente da categoria canibalismo, a acusação registrou termos como comer órgãos e beber sangue em uma sessão de atos repulsivos e condenáveis, ao passo que a defesa elegeu como fio condutor lexical categorias como retirar os órgãos e infração penal, sendo tácito que os dois lados, contudo, transformaram a categoria canibalismo em vilipêndio a cadáver.

A mutação metonímica não foi gratuita. Do lado do Ministério Público, enquanto nos discursos midiáticos G. é transformado em 
canibal, nos autos, a não incidência nas alegações da acusação daquela categoria parece prestar-se menos a uma tentativa de civilidade ou educação gramatical, e mais a uma categorização metalinguística de explicação da palavra (canibalismo) para comover e indignar o magistrado e o júri pela ideia em si; ao mesmo tempo em que se tenta domesticar legalmente o conceito de canibalismo. $\mathrm{O}$ ato descrito de comer o fígado e beber o sangue, a elucidação em detalhes do modus operandi, pautada nas fotos e nos laudos, choca, em termos semânticos, muito mais do que a afirmação livre de que G. é um canibal, esvaziada de força emotivo-argumentativa pela taxatividade da afirmação.

Paralelamente, a descrição minuciosa do ato de canibalismo nos textos acusatórios possibilita a conformação metonímica do acontecido à categoria de vilipêndio ao cadáver, semanticamente próxima ao magistrado e legalmente condenável. Voltando a Das $(2007,2008)$, a violência aparece discursivamente construída na tensão e no processo entre um extraordinário - canibalismo - que se torna ordinário - vilipêndio ao cadáver - sem, contudo, perder a força de choque graças ao respaldo dos laudos, fotos e descrição direta do ocorrido. $\mathrm{O}$ enfoque da denúncia recai no processo de mutação metonímica e não na extremidade significante já consolidada vilipêndio. Para a acusação, reforçar o significado (comer e beber) e menos o significante (vilipêndio ou canibalismo), atesta tanto uma força emotiva usada taticamente na comoção do magistrado, a partir do proposto por Bailey (1983), quanto uma possibilidade lexical de estabilização do significado do ato (canibalismo) em termos de um significante legalmente estruturado (vilipêndio), valendo lembrar ainda que o tipo penal "vilipêndio a cadáver" engloba não só os atos de canibalismo, mas também todos os demais atos feitos contra o corpo no intuito de ofendê-lo.

Por outro lado, a mutação metonímica serve à defesa pelo que constrói, no universo jurídico, ao final do processo linguístico- 
discursivo: a categoria vilipêndio ao cadáver estabilizada enquanto categoria legal. Fugindo da descrição do ato em si, a defesa, ao não falar do ocorrido em pormenores, ao não citar o comer órgãos ou o beber sangue, mas dialogar no registro direto da infração penal e do vilipêndio, transforma a domesticação do ato em uma conformação semanticamente plana, pronta, definida e menos agressiva, apreendida pelo lado do significante já estabilizado, legalmente condenável e menos reprovável do que a categoria canibalismo e seu significado intrínseco. A estratégia discursiva de focar na extremidade e não no processo, no significante final (canibalismo transformado em vilipêndio) e não no significado (comer o fígado, beber o sangue), surge como uma potência significativa que possibilitaria a não apresentação de G. como um monstro canibal, resvalando em uma configuração menos agressiva do acusado.

O jogo entre acusação e defesa tem uma carga lógica que deriva do universo jurídico em si, da caracterização taxativa dos elementos do homicídio e do vilipêndio ao cadáver - legítima defesa, homicídio qualificado, laudos, materialidade ou não do ato, atenuantes e agravantes - que são trazidos à baila pelos dois lados. Ao mesmo tempo, seria ingênuo supor que os conflitos jurídicos basear-se-iam apenas em regras lógicas, como se a razão excluísse a emoção em um plano ontológico dado de fundo. Ao lado daquelas regras "claras", há a atuação de elementos outros, dentre os quais uma espécie de emotion work (CLARK, 1997, p. 13) que ganha relevo.

O extraordinário esfumaçou o homicídio, recaindo sobre o ato de canibalismo/vilipêndio a cadáver. G. ganhou projeção midiática nacional pelas possibilidades acerca da sua caracterização como canibal, independentemente das suas qualificações pessoais, não havendo, por exemplo, menções substanciais à sua idade, sexualidade ou condição social na reconstrução discursiva da cena e do contexto do crime nos autos - somente para X., no seu interrogatório, foi-lhe 
perguntado diretamente sobre seu relacionamento com A. e G., a fim de, aparentemente no teor do registro, configurar o ciúme como causa dos delitos. Sobre condição social ou sexualidade, G., por outro lado, parece ter sido inquerido sem maior profundidade, constando referências secundárias nos documentos escritos quanto ao triângulo amoroso, às condições de vida ou à sexualidade dos envolvidos. Foi, assim, o inusual do caso - o canibalismo/vilipêndio a cadáver - que parece ter se projetado maximizado entre os documentos do processo e para fora dele.

Como visto, no curso da ação penal, a categoria canibalismo transformou-se em vilipêndio, atendendo tanto às demandas da acusação, quanto às da defesa. Paralelamente, a partir da cadeia lexical e da descrição empreendida por ambas as partes, cada uma procurou ensejar uma reação específica no juiz, imediatamente (e nos jurados, mediatamente). Assim, em primeiro lugar, no discurso da defesa, G. foi apresentado, no caso do homicídio, como alguém que defendia sua integridade física contra o enciumado A., o verdadeiro algoz, enquanto em relação ao crime de vilipêndio, não haveria provas suficientes de sua materialidade, além de que, gramaticalmente, o ato de comer órgãos e beber sangue virou uma infração penal.

Candace Clark (1997) define a compaixão ou simpatia como uma emoção ligada à demarcação de status sociais. A elaboração cognitiva e discursiva de um sentimento, usado taticamente para impor um convencimento, age sobre a qualidade desse próprio sentimento, de maneira que a simpatia, como o amor, é um fenômeno guiado socialmente (CLARK, 1997). Convencer o juiz e os jurados da inocência de G. tornou-se um trabalho tanto lógico-jurídico, quanto emotivo-moral: G. deveria aparecer, necessariamente, como uma figura que exerceu legítima defesa e que não era um canibal, mas um infrator penal, capaz de ser objeto de simpatia na exata medida em que a possibilidade de despertar compaixão funciona como uma 
possibilidade de debate de questões de justiça e moralidade: "sympathy contributes to the social order by connecting the unfortunate to the fortunate, by offering temporary breaks from coping with life's difficulties, and by creating a wider circle for commentary and debate on issues of justice and morality" (CLARK, 1997, p. 16).

No discurso quanto ao crime de vilipêndio ao cadáver, a dinâmica sintático-semântica descrita pela defesa para desfigurar o suposto ato de canibalismo serviu a uma intenção intrínseca de afastar G. da figura de um monstro. Ser objeto de compaixão ou simpatia, nos termos de Clark (1997), é um papel afetivo que deve ser desempenhado na interação social, obedecendo a regras morais específicas. Transmutado para as formas escritas do processo, a defesa, afirmando que G. exerceu legítima defesa e que estava fisicamente longe, de acordo com o depoimento, do momento de violação do corpo da vítima, pareceu tentar caracterizá-lo de uma maneira mais compassiva diante do magistrado. Se a compaixão e a simpatia delimitam um status social, e se ser objeto de simpatia é um papel afetivo preso a uma economia socioemocional e a uma etiqueta moral, afastar G. da figura do canibal e aproximá-lo da de infrator era gramaticalmente fundamental para tentar estabelecer vitoriosamente a absolvição. Simpatizar-se com alguém exige, para Clark (1997), a direta capacidade de ser objeto de simpatia: se G. aparecesse como canibal, essa possível compaixão/simpatia seria infinitamente mais difícil de ser atingida face ao juiz. Restaram os recursos descritos de enfatizar o vilipêndio ao cadáver como infração penal, longe dos significados de comer órgãos e beber sangue.

Em segundo lugar, do lado da acusação, a estética discursiva ganha outro tom. Os depoimentos e as supostas atitudes de G. são configurados a partir de uma estratégia de convencimento e comoção cujo empuxo é a mobilização do juiz e dos jurados para condená-lo. $\mathrm{O}$ ato violento passa a ser moralizado negativamente pelo discurso do 
Ministério Público a partir de uma configuração que tende a realçar certos caracteres para evidenciar o "monstro" que G. é, principalmente o comer órgãos e beber sangue. Aliada às fotos e aos laudos, a temática acusatória catalisa ao máximo um impacto estético para culpabilizar o acusado, obscurecendo-o.

Boltanski (1993) define que a tópica da denúncia tem o condão de deslocar a atenção dos espectadores em direção a um culpado. Incidindo diretamente sobre um responsável, identifica-se um indivíduo como o culpado imediato pelo sofrimento causado à vítima. Por outro lado, a denúncia pode agir também mediatamente, realocando acusados e vítima em um espaço simbólico diferente no qual estão interligados por uma corrente sintática e semântica de causalidade (LOWENKRON, 2012).

O Ministério Público teria, enquanto instituição definida legalmente, a competência e o papel moralizador de representar o sofrimento alheio, no caso, o da vítima A.. No espaço dos autos do processo, a tarefa acusatória é relacionar G. à identidade do autor através da materialidade dos fatos, dada pelos depoimentos, fotos e laudos técnicos. A cadeia lexical utilizada e realçada a partir dos depoimentos, as fotos alocadas no processo, os laudos que, idealmente, não deixariam margem para dúvidas, tudo parece pretender fazer com que o juiz e, mais tarde, o júri, saia do simples estado de torpor, susto ou nojo para o de indignação (BOLTANSKI apud LOWENKRON, 2012, p. 114), válvula ativa para a condenação buscada pela denúncia.

No espaço simbólico dos autos, compilado a partir da lógica da causalidade, o discurso acusatório, ao se pautar naqueles depoimentos, fotos e laudos técnicos, aciona categorias que dão forma e realidade para o sentido buscado na denúncia, realocando e recriando certa ordem (causal e semântica) para os crimes, estes imediatamente tidos como inexplicáveis. Dar um sentido a esses atos, com o objetivo de provocar indignação nos julgadores e castigar o culpado, 
necessariamente precisa daquelas vozes de especialistas, reforçando a gramática discursiva do Ministério Público de fazer efervescer a descrição dos atos canibalescos ao invés de apenas suscitar a categoria mais limpa de vilipêndio ao cadáver ou a categoria semanticamente descarregada de canibal.

Fazer ver o que "realmente" aconteceu e trazer uma voz idealmente longe de qualquer suspeita são o suporte necessário para causar indignação diante das descrições minuciosas da acusação. A posição do denunciante obriga a uma postura que faça a ação de julgamento orientar-se em direção ao culpado. Tal orientação da atenção na busca por uma ação definitiva envolve, como parte tópica da denúncia (BOLTANSKI, 1993; LOWENKRON, 2012), um conjunto de provas que dinamizem e apoiem a realidade a partir dos objetos. Aqui, as fotos e os laudos, objetos por excelência, ao lado dos depoimentos, arregimentam o discurso denunciante contra o denunciado imoral e culpado.

A narrativa das peças acusatórias dos laudos pretende dar irrefutabilidade ao sentido punitivo. O laudo de exame de corpo de delito narra a morte em termos técnicos que dão sentido e veracidade material às falas mais abertas dos depoimentos, estando esta narrativa amparada pela tácita, antecedente e pretensamente inegável legitimidade dos especialistas. Segundo o laudo, a morte caracterizouse por "midríase paralítica, ausência de respiração e circulação, hipotermia, rigidez muscular nos 4 membros" (Processo, 2007, p. 36), e a causa mortis "procedeu-se em virtude do choque hipovolêmico, secundária a ferimentos corto confuso e perfuro incisivos" (Processo, 2007, p.37). Ademais, o laudo descreve em detalhes médicoanatômicos todos os ferimentos no pescoço, face, tórax e abdômen, além de dar especial atenção ao fato de que a genitália fora "amputada do segmento corporal, sendo que o produto da castração correspondia a bolsa escrotal, testículo e prepúcio" (Processo, 2007, p.37). 
Já o parecer técnico número 2450 sobre local de morte violenta, salpicado de fotos do corpo retalhado de A., também descreve a aparência e os ferimentos da vítima, ressaltando que "parte das vísceras da vítima foram 'arrancadas' do interior do seu corpo e espalhadas pelo local" (Processo, 2007, p. 71). Por fim, a reprodução simulada dos fatos, contando com a presença de G. e X., arrebata a versão única que descreve toda a cena: horários, a bebida alcoólica que teriam ingerido (cachaça Jamel), o agente ativo e passivo durante a relação sexual, as frases ditas, o tipo de faca que G. usou (peixeira), e, enfim, a dinâmica do vilipêndio ao cadáver/canibalismo, entre fotos que mostram o acusado retalhando e esfregando-se a um boneco de plástico de tamanho natural:

[...] Prosseguindo com os ataques ao corpo já praticamente sem vida de A., G., que permanecia com a faca na mão, faz um corte na região anterior do pescoço (garganta), retirando os últimos sinais de vida da vítima. $\mathrm{Na}$ sequência, X. e G. permanecem, abaixados, ao lado do corpo e, virando o mesmo lateralmente, $X$. fala (em relação às nádegas): "Olha... Que gostoso!". Então, G. "retira" seu pênis da calça e, aproximando-se do corpo, esfrega nas nádegas da vítima, rindo e falando: "Gostoso...!". Após realizarem esse ato, deixam o corpo na posição anterior (decúbito dorsal) e, G., pegando novamente a faca, faz uma grande incisão, iniciando-se no tórax e prolongando-se até o abdômen, de onde retira as vísceras (intestinos, coração, fígado e outras), espalhando ao redor do corpo, no chão. Durante isso, X., com a faca, faz diversas perfurações espalhadas pelo corpo da vítima. Prosseguindo com o ato macabro, G. pega um pedaço do fígado retirado da vítima e come alguns pedaços. Corta um pedaço e oferece, em seguida, a X. que dá uma mordida no pedaço do fígado e joga ao lado do corpo, dizendo: “É ruim... É amargo, não vou comer não". Segundo X. e G., ambos permaneceram "brincando" com os órgãos da vítima, sendo que, após cortarem (retalharem) parte do fígado, colocaram em uma frigideira, mas não chegam a fritar. Em seguida, G. pega um copo, tipo americano que estava sobre a mesa, enfia dentro do corpo da vítima e retira com cerca de $3 / 4$ 
de sangue e bebe. Logo em seguida, passa o copo a X., com um pouco de sangue que restou e pede para o mesmo tomar. Este se recusa a beber o sangue e, diante de tal recusa, G. joga o sangue do copo em X., ensopando sua roupa. Logo após G. jogar o restante de sangue do copo em X., ele se dirige ao menor infrator e diz: "Vai até a Delegacia e fala que você matou A.". O menor sai do local, todo ensanguentado, bastante perturbado com o que aconteceu e, também, em virtude à quantidade de bebida alcoólica que ingeriram, se dirigindo até a Delegacia, que estava localizada a cerca de 500,0 m do local, relatando tais fatos. G. permanece por mais um tempo e ainda toma mais um copo de cachaça para, em seguida, sair em direção a sua casa (Processo, 2007, p. 83-85).

O contexto e a imagem que os laudos perfazem coalizam os três corpos (G., X. e A.) em uma cena que serve à acusação para deslocar, voltando a Boltanski (1993), qualquer comoção em relação à vítima na direção de uma indignação face ao acusado. Se "um sentimento tem mais chance de se cristalizar em torno de uma foto do que de um lema verbal" (SONTAG, 2003, p. 72), a intercalação das fotos com as descrições minuciosas tende à cristalização de uma indignação não complacente que permite recriar o fato em torno de um sentido novo, indubitável, que vincule o julgador ao algoz através do desprezo e do nojo (MILLER, 1997). A., enquanto vítima, cujo corpo retalhado, nu e ensanguentado protagoniza as fotos, é a ponte semântica causal que o processo reconstrói entre G. e quaisquer juízes, oficiais ou leitores. Surge o canibal e o homicida sem que, em nenhum momento, nem as fotos, nem as falas, enunciem tais identidades.

Se a defesa tenta recriar G. como infrator e defensor da própria vida, parecendo utilizar-se da tentativa emotivo-argumentativa de construir uma aura de simpatia ao seu redor para afastá-lo da crueldade e repulsividade dos atos; a acusação, com as fotos cruas, as descrições minuciosas e tendo a seu lado vozes dos especialistas, parece transferir o nojo em potencial que as fotos poderiam causar em si, se distantes 
do contexto, para a figura do acusado, tornando-o repugnante no lugar das fotos, ou melhor, ao lado e por causa das fotos e falas. Aqui, tal qual a simpatia descrita por Clark (1997), o nojo, argumenta Ian Miller (1997), também é uma emoção de demarcação de status, um sentimento moral cujo poder desestabilizador marca uma alteridade entre dois atores sociais de status diferentes, diminuindo o inferior em face do outro, superior, através da fixação clara dos limites entre categorias de bem e mal, puro e impuro, e da capacidade de poluição que o inferior exerce na dobradiça entre aquelas demarcações. As falas e fotos, com sua capacidade intrínseca de contaminar, foram utilizadas discursivamente para recriar G.: ele fora metamorfoseado, alvo do nojo que aquelas fotos trazem potencialmente em si, e de outro nojo, mais sutil, criado na sua própria pessoa de acusado pelo uso daqueles níveis visual e textual, fazendo-o ser o objeto passivo da repugnância das fotos e um sujeito ativo que inspira desprezo, condenável em seus atos. Similar às palavras de Miller sobre seu encontro com um pedreiro, surge, metaforicamente, o monstro:

[...] it wouldn't take much for this basic mechanic to metamorphose into a monster. Horror can be frightening, or it can be repulsive and disgusting. And while contempt can be a kind of defense against a fear of the contemptible, it also bears some close connections with disgust. [...] In a sense, he was contaminating. The notion of pollution and contamination is part of what disgust brings to the world of contempt (MILLER, 1997, p. 209).

As retóricas e poéticas que defesa e acusação levantaram tentaram recriar G. e dar sentido a seu ato. Cada uma definiu um G. e um tipo de violência. Por entre o labirinto de significados que um ato violento pode adquirir quando reconstruído em outro universo sintático-semântico, foi a busca de condenação ou absolvição que motivou o uso tático tanto das argumentações emotivas, quanto das lógicas. Tentar evidenciar a materialidade do fato e sua autoria em 
uma lógica causal chapada, no processo, incendiou as diversas faces do mesmo ato. Assim, entre provas objetivas, materialidade factual e autoria do crime, o papel de convencer nunca se baseia, exclusivamente, em objetividade versus subjetividade.

$\mathrm{Na}$ cadeia de reconstrução causal de significados nos autos, é do encontro entre um emotion work com um logic work que a crença em uma das versões, a que pareça mais verossímil ao julgador, baseiase. Falas, fotos, certezas e incertezas formam um mosaico aberto e sempre passível de remendas, cuja escolha da imagem que efetivará o julgamento requer um trabalho incessante de recriação do fato, várias e várias vezes, ao longo de 447 páginas, seja pelas vozes dos participantes, pelas fotos, pelas vozes dos especialistas, das partes ou dos policiais. A criação de um sentido final deu-se pela recriação exaustiva dos fatos, versão após versão, e pela reedição incansável dos significados fabricados das provas em um espaço-tempo e em uma gestão moral e política específicos, o da ação penal. A moralidade ou imoralidade surgiu nos interstícios das dinâmicas que ocorreram a partir da noite de 23 de Novembro de 2007, transmutados para folhas de papéis. Na avaliação final, enfim, ao magistrado coube apenas a escolha de uma das imagens plausíveis do mosaico semântico criado nos diálogos e monólogos entre as partes.

\section{VII}

Na sentença de pronúncia, o juiz, em abril de 2009, decidiu sobre o juízo de admissibilidade da acusação para levar o réu ao Tribunal do Júri. Para o juiz, a existência do crime restou comprovada graças ao Laudo de Exame de Corpo de Delito/Exame Necroscópico presente no processo. Sobre a autoria, entendeu que houve indícios suficientes de que o acusado teria desferido golpes de faca contra a 
vítima, com base nos depoimentos coletados. Quanto à tese da defesa, julgou que esta não conseguiu comprovar-se para fins de absolvição sumária, devendo ser rediscutido tal mérito no Tribunal, em virtude do princípio do in dubio pro societae que vigora nesta fase processual. Ainda qualificou-se o homicídio por dificuldade de defesa da vítima e por motivo fútil - ciúmes -, graças aos depoimentos ouvidos em juízo. Definido, então, o Tribunal do Júri para Julho de 2009, às oito horas e trinta minutos da manhã, encerra (e decide) o juiz.

\section{VIII}

Nos discursos apresentados, há uma assimetria que sobressai mais no plano filosófico-antropológico do que no legal. No Direito, embora idealmente (e ingenuamente) na letra da lei apenas o ato em si seja julgado, e não a pessoa do criminoso, as motivações, por vezes, são levadas em consideração, podendo qualificar o crime, agravá-lo ou atenuá-lo, ou ainda agir como causa excludente de ilicitude. No homicídio do qual G. fora acusado, o debate entre defesa e acusação perpassou pela motivação: se o Ministério Público acusou-o de praticar crime por motivo fútil - ciúmes, a defesa tentou usar a ideia de legítima defesa como motivo para o assassinato, tentando absolvêlo sumariamente.

Nas páginas do processo, apesar de legalmente esperado, embora antropologicamente curioso, não houve qualquer indagação sobre os atos de canibalismo. Mesmo a tentativa da defesa, que restou superada por laudos psiquiátricos, de sinalizar uma potencial anormalidade ou insanidade mental de G., não focou no vilipêndio a cadáver, mas apareceu como uma fraquíssima possibilidade que perpassaria todo o caso, do homicídio ao vilipêndio. Nessa seara, óbvio que não cabe entender ou explicar os motivos do canibalismo: os porquês são a zona cinzenta, o ponto máximo de capacidade de 
linguagem e significação a que se consegue chegar. Por que G. comeu o fígado? Por que bebeu o sangue? Por que $\mathrm{X}$. o seguiu? Tais são os limites inenarráveis da violência, ao menos no plano jurídico-legal chapado do processo.

Se, voltando a Veena Das $(2007,2008)$, no limite do inteligível, violência não existe, mas deve ser sempre reativada contextualmente nos significados a cada narrativa e temporalidade novas, os limites semânticos dados dentro dos autos (e fora deles) perpassa aqueles porquês, que permanecem silenciosos e zonas cinzentas. A pergunta por que G. e X. comeram os órgãos de A. é válida? A resposta é mais um plano de silêncio que envolve a violência efetuada.

Mesmo correndo o risco de ingenuidade intelectual, mas pensando nos mesmos moldes fictícios que, a partir dos elementos constantes nos autos, formaram o convencimento do juiz de que o crime de homicídio fora cometido por motivo fútil, a trilha que se evidencia para criar suposições sobre o porquê do canibalismo passa por uma outra emoção/ação, a humilhação, que parece atingir e modular status sociais em um plano mais profundo do que a simpatia e o nojo fazem gramaticalmente.

Adentrando o indizível, Jack Katz (1988), pensando sobre crimes de homicídio nos quais há uma desproporção entre a atitude que desencadearia o ato e o resultado morte consequente, entende que na relação dialógica entre vítima e algoz, o segundo age impelido por uma ira que lhe é justificável pelas atitudes da vítima, que estaria atacando valores humanos que the são caros demais. $\mathrm{O}$ criminoso então, a partir de um processo emocional particular, sente a humilhação profunda que a vítima lhe encalca e a projeta para o futuro, sentindo sua identidade para sempre manchada pelo presente da agressão que a vítima lhe impôs, em seguida transformando a humilhação em uma espécie de "ira santa" (REZENDE; COELHO, 2010) que culmina no ataque à vítima, na tentativa de manter, no agora, uma unidade 
moral sacrossanta da sua identidade, eliminando a humilhação, transcendendo-a, recuperando respeitabilidade. Sobre o ataque, "It is the outcome of the embrace of righteousness as a means to the perfect resolution of humiliation through the overwhelming sensuality of rage" (KATZ, 1988, p. 24).

Nos autos, foi A. quem atacou primeiro ao ver G. na cama com X. Alocando sua atitude em sintonia com a proposição de Katz, a humilhação que sentiu pela cena e a consequente tentativa de defesa da sua honra ("você não falou que iria transar apenas comigo?") impeliram-no ao ataque, sua "ira santa", esfaqueando G. na busca pela superação da humilhação. O contraponto, contudo, foi o revide de G.: parece - com base nas "provas" dos autos - que ele não teria agido por sentir-se humilhado. Torcendo, assim, o trajeto emocional de Katz, G. teria acessado o estágio da raiva diretamente para defender-se das facadas, uma vítima metamorfoseando-se em algoz, talvez assustado, talvez irado, mas com certeza enraivecido pelo ataque, matando A.

A questão que se levanta vem do ato contínuo: se a humilhação demarca o status inferior daquele que a sofre, aparece como complemento necessário o fato de que aquele que humilha pode sentir-se, pelo ato, como elevando seu status. Retalhar o corpo de A., comer seus órgãos, beber seu sangue, transformando-o, enfim, em mera carne sem humanidade, corpo desumanizado, comida, não poderia ser entendido como o ápice da atitude de humilhar? Passar o pênis nas suas nádegas, cortar seu pescoço, "brincar" com seu corpo, não seria a modulação que a própria cena e ativações emocionais em jogo deram como sustentáculo máximo da força sedutora que humilhar alguém desperta? Os significados do comer não teriam sido, assim, redefinidos em torno do humilhar A.? Se este saiu, na dinâmica de Katz, da humilhação para a raiva, G. não teria saído da raiva para o ato de humilhar como ápice da sua ira? 
Novas perguntas e porquês que escampam o limite do narrável. Mero exercício elástico de possibilidades interpretativas acadêmicas. Tentativas de análise que se baseiam em possibilidades intrinsicamente demarcadas pelo indizível. Seduções analíticas que transpassam os limites de averiguação, mesmo metafórica. Cadeias causais, enfim, marcadas pelas zonas escuras, fantasmagóricas, da violência e do ser humano, ou melhor, do quando se é possível ser humano. Devaneios e mais silêncios.

Fim de caso. (?)

\section{REFERÊNCIAS}

BAILEY, Frederick George. The tactical uses of passion. An essay on power, reason and reality. London: Cornell University Press, 1983.

BOLTANSKI, Luc. La souffrance a distance: Morale humanitaire, médias et politique. Paris: Éditions Métailie, 1993.

CLARK, Candace. Misery and company: sympathy in everyday life. Chicago/ London: University of Chicago Press, 1997

DAS, Veena. Life and words: violence and the descent into the ordinary. Berkeley: University of California Press, 2007.

DAS, Veena. Violence, gender and subjectivity. Annual Review of Anthropology, Palo Alto, n. 37. p. 283-299, 2008.

KATZ, Jack. Seductions of crime: moral and sensual attractions in doing evil. New York: BasicBooks, 1988.

LOWENKRON, Laura. O monstro contemporâneo: a construção social da pedofilia em múltiplos planos. Tese (Doutorado em Antropologia Social) - Museu Nacional, Universidade Federal do Rio de Janeiro, Rio de Janeiro, 2012.

MILLER, William Ian. The anatomy of disgust. Cambridge: Harvard University Press, 1997.

RANGEL, Paulo. Direito processual penal. 18. ed. Rio de Janeiro: Lumen Juris, 2010. REZENDE, Claudia Barcellos; COELHO, Maria Claudia. Antropologia das emoções. Rio de Janeiro: FGV, 2010.

SONTAG, Susan. Diante da dor dos outros. São Paulo: Cia das Letras, 2003. 